\title{
Latin learning materials in light of the papyri
}

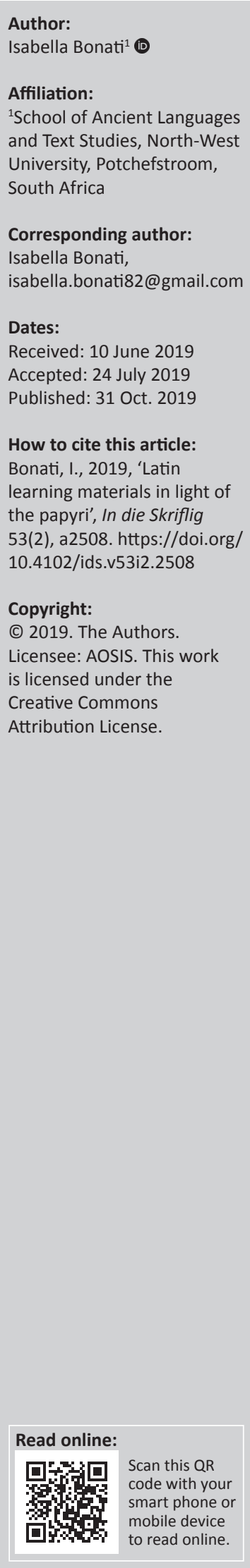

The aim of this article is to provide an overview of the ancient materials used in teaching Latin in order to recreate the ancient Latin teaching and learning experience. Particular attention is devoted to the case of Greek speakers learning Latin. To reconstruct this picture, the evidence of the papyri from Egypt plays a fundamental role. Papyri attest to the various phases of Latin instruction for Greek speakers, ranging from an elementary to an advanced level, and they also shed light on the typologies of texts that were used. Among the Latin learning materials, this article focuses on papyrus texts intended for aspiring lawyers and law students as a striking example of the practical advantages of the acquisition of Latin in Roman Egypt. Using this material, we can draw some significant parallels between ancient and present teaching of Latin in the context of legal studies with special emphasis on the case as it is in South Africa at present.

Keywords: Papyri; Latin language; Greek language; legal studies; legal comparison; GraecoRoman Egypt.

\section{Latin learning materials: Introduction, overview and context}

The aim of this article is to examine the Latin learning materials, focusing on the case of Egyptian Greek speakers learning Latin. In order to reconstruct the picture of a Latin learning experience by Greeks, the evidence of the papyri makes Egypt a privileged case study. Given that the vast majority of the extant texts on papyrus survive from Egypt (for climatic reasons), our knowledge of the Latin learning process is strictly dependent on what that process was in the Egyptian context. Ancient papyri bear direct and concrete witness to the everyday life of the past, and they preserve the texts used by the ancient students to learn Latin. Therefore, they help to answer questions such as who learned Latin in Egypt, and why and how.

The materials on papyrus, addressing the acquisition of Latin, cover the entire period of Roman rule in Egypt, ${ }^{1}$ from 30 BC to AD 641, during which Egypt became a key Roman province. Yet, the bulk of these texts date from the 4th century, on when the learning of Latin became more widespread. ${ }^{2}$ In general, Egypt has provided a huge quantity of educational material that allows us to gather information on the everyday practice of teaching and learning in the Egyptian chora. ${ }^{3}$ Some of the papyri found in Egypt that are entirely written in Latin could have belonged to Latin native speakers that were living in the province as members of the Roman elite. ${ }^{4}$ However, a reliable means to identify Latin learning materials used by Greek-speaking citizens, is the presence of a translation of the Latin passages into Greek, or at least of Greek transliterations as well as Greek explanations and glosses.

Latin learning materials - mostly grammatical works and glossaries - have also reached us via the medieval manuscript tradition. ${ }^{5}$ Yet, papyri attest to learning stages and modalities such as the

1.The oldest extant document and the only one dating back to the 1st century BC, is BKT iX 150 (MP3 2134.5 , Trismegistos [henceforth, LDAB] 6764), found in Bousiris and preserving a Greek-Latin glossary with grammatical annotations with the Latin transliterated into Greek script. Whereas the most recent one dates back to the 6th-7th century AD, P. Heid. inv. L 4 (MP3 2966, LDAB 2557), and contains Justinian's Digesta with Greek notes (for an overview of the Latin learning materials on papyrus, see Dickey 2016:178-182). The editions of the papyri are mentioned according to the abbreviations established in the Checklist of Greek, Latin, Demotic and Coptic Papyri, Ostraca and Tablets (Oates \& Willis 2011).

2.Compare Cribiore (2007:47, 58-59), especially: It was argued recently that there was no official policy at the time of Diocletian to raise the status of Latin, and this is probably true. Yet one cannot underestimate the fact that most of the Latin and bilingual papyri preserved (documents along with literary and semi-literary texts) date from the period after Diocletian (p. 58).

On the historical reasons why the knowledge of Latin became more widespread, see Gaebel (1969-1970:291-293, 295-296) and Internullo (2011-2012:31-33).

3.On the topic of education in the papyri, see Cribiore (1996; 1997:53-60; 2007:47-66; 2009:320-337)

4.Compare Cribiore 2007: An important caveat is that it is very difficult to identify with certainty the readership of books of authors written entirely in Latin, since they might have been used by Roman citizens, and they rarely bear traces that they were handled exclusively by Greeks. (p. 61; see also Gaebel 1969-1970:286)

5.For an overview of the texts surviving via the medieval manuscript tradition, see Dickey (2016:182) 
use of transliterated texts and preliminary approaches to alphabet learning, which have no parallel in other sources. As Dickey (2016) states:

These texts have the advantage of being securely datable to antiquity and do not contain post-antique corruptions (though they may contain corruptions that arose in antiquity). Most of the papyri are too fragmentary to be individually usable today, but collectively they allow us to build up a picture of what ancient students did and how common each type of languagelearning activity was in comparison to others. (p. 6)

During the Roman Empire, Latin was learned not only by Roman children who were taught by their own parents, by pedagogi or at school, but also by adults who learned it as a foreign language. Latin spread rapidly among the populations conquered by Roman forces in the various parts of the growing empire. Yet, whereas in the western empire Latin became the main language, in the pars Orientis of the Empire, Greek remained the chief language. ${ }^{6}$ In Roman Egypt, the Latin-Greek language contact produced evident bilingual results, especially in milieus such as the army, the civil administration and the judiciary in which Latin was the language of the new ruling power. Papyri from Roman and Byzantine Egypt provide invaluable insights into this phenomenon. ${ }^{7}$ In the complex contacts and interactions between Greek and Latin, it seems more appropriate to talk of 'Latin in Egypt' rather than 'Latin of Egypt' (cf. Adams 2004:527-528; Scappaticcio 2015:14).

The experience of Latin as a second language has several affinities with ours today, as ancient learners had to study declensions and conjugations, use dictionaries, memorise vocabulary and read texts. On the other hand, even if they struggled with the Roman alphabet, they were accustomed to the morphological concepts of gender and declension (cf. Dickey 2016:1). In addition to this, their learning would, to some extent, be immersive, for they would hear some Latin in their context.

It is likely that in Roman Egypt, the Latin learning practice took place outside the formal educational environment of the school. What we know of this practice is inferred exclusively from the materials on papyrus. There was a substantial difference between Romans learning Greek and Greek speakers learning Latin: the former did it as school children, the latter did not. The reason for this different attitude towards the learning of a second language was basically a matter of language prestige. Knowledge of Greek was crucial in the curriculum studiorum of a well-educated Roman, hence Roman parents ensured that their children learned it from the early years: during the empire all elite children had to learn Greek at school, but literate Romans still knew Greek in the Byzantine period. The Romans had a reverent attitude towards Greek language, literature and culture. In contrast, Greek speakers learned Latin as young adults when they

$6.0 n$ this linguistic difference between the two halves of the Empire, compare Dicke (2015a:30; 2016:1-2) as well as Internullo (2011-2012:30-31).

7.Among the numerous bibliography on the topic, compare Gaebel (1969-1970:289-296) Rochette (1996a:153-168; 1996b:57-79; 1997; 2010:281-293), Adams (2004:527-641), Fournet (2009:421-430) and Evans (2012:516-525) with references. needed to know Latin while training for certain professions (cf. Cribiore 2007:59-60; Dickey 2016:3; Rochette 1997:69-83, 260). In general, the Greeks were not particularly interested in Roman literature and culture, and considered Greek superior to any other language.

Papyri attest to the various phases through which Greek speakers passed while learning Latin in Egypt, ranging from an elementary to an advanced level. They also shed light on the typologies of texts that were used. ${ }^{8}$ Materials for the early stages of learning, include the Latin alphabet. It was often accompanied by the equivalents of Greek letters or the names of Latin letters in Greek. ${ }^{9}$ Then, transliterated texts aimed at acquiring oral proficiency. ${ }^{10}$ Finally, texts easy to be read by beginners were usually divided into two narrow columns: the first in Latin, the second occupied by a line by line Greek translation. This enabled the learner to understand the meaning of both the individual words and the whole sentence. These bilingual texts find a parallel in modern interlinear and facing-page translations (cf. Dickey 2015b:807-821; 2016:4). Many of them belong to the category of the colloquia, because their contents were mostly penned in dialogic form. ${ }^{11}$ The colloquia were characterised by simple syntax, short sentences and basic everyday vocabulary, and facilitated learning common vocabulary in context. It is possible that the learners memorised extracts in Latin, supporting their understanding of the text by means of the Greek translation, and then recited the sections to their teacher. Ancient learners also needed grammar, which were conventionally written in the target language regardless the learner's native language. ${ }^{12}$ More advanced levels of instruction could perhaps entail prose composition such as rewriting extracts of authors or translating Greek passages into Latin, but we have almost no evidence of such exercises. ${ }^{13}$ Students could occasionally learn Latin well enough to challenge themselves and successfully read Latin texts without the Greek translation (cf. Dickey 2015a:48; 2016:5). In these cases, while studying the monolingual texts, they used to add glosses on, or translations of the difficult words in the margins or in the interlinear spaces. To look up the meanings of the words, they made abundant use of lexica and glossaries with the Latin often transliterated into Greek: some of these were thematic glossaries in form of classified wordlists, while others were arranged in alphabetical order. ${ }^{14}$ Bilingual glossaries, presenting the Greek equivalent of the Latin words, were also popular in Egypt: they belong to a bilingual

8.Compare Cribiore (1996:29-30; 2007:60), Fournet (2009:428), internulio (2011-2012:33-34), Sánchez-Ostiz (2013:150), Dickey (2015a:3, 32-33, 35; 2016:6, 121-127) for specimens, and Scappaticcio (2015:7).

9.Compare Dickey (2015a:35-36; 2016:119-120) for specimens as well as Scappaticcio (2015:52-52, 65-90) for further examples.

10.For specimens, see Dickey (2016:121-127).

11.Compare Dickey (2015a:36; 2016:4-5, 10-58) for specimens.

12.Compare Dickey (2015a:33-34, 38-42; 2016:5, 83-99) for specimens. For a survey of all the Latin and bilingual Artes Grammaticae on papyrus, see Scappaticcio (2015).

13.Compare Sánchez-Ostiz (2013:152) and Dickey (2016:6, 116-118) for P.Amh. II 26 (III-IV AD; MP3 172, LDAB 434), a papyrus preserving a set of fables of Babrius in Greek with Latin translation as a possible specimen, but consider the doubts expressed in Dickey (2015a:49-51).

14.Compare Dickey $(2015 a: 45-47 ; 2016: 5,100-115)$ for specimens. See also Scappaticcio (2015:39-47, 433-471. 
category of text that will result in the medieval tradition of the Hermeneumata. ${ }^{15}$

The very first Latin literary works read by ancient learners were the early books of Virgil's Aeneid for poetry and Cicero's Catilinarian orations for prose. ${ }^{16}$ Several copies of these texts survive in bilingual format, and this means that they were already used by beginners. Latin literature read in Egypt for didactic purposes also encompasses other authors: Juvenal, Terence, Livy, Seneca, Lucan and Sallust. ${ }^{17}$ When these texts do not offer a Greek translation, but just Greek glosses or notes, this points to a higher stage of learning Latin.

Although these papyri show that Greek speakers made also use of Latin authors to learn the language, they did not have the aim of appreciating Roman literature for its own sake: their purpose was primarily practical (cf. Cribiore 2007:62; Dickey 2015a:43; Fournet 2009:428; Gaebel 1969-1970:291; Internullo 2011-2012:32-33; Rochette 1997:174-177, 196; Sánchez-Ostiz 2013:152; Scappaticcio 2015:13). The exercise of a given profession, such as an administrative position in the imperial bureaucracy and the practice of law (see infra), was the main reason to learn Latin in Egypt. As Brashear (1981) points out:

Soon after the battle of Actium someone very eager to learn the language of the new rulers set out to study Latin even before he could properly read it. The economic and social advantages it would bring him were strong incentives. (p. 34)

The Roman army was another influential environment in which people learned Latin for practical aims (cf. Adams 2004:617-623; Dickey 2015a:31; 2016:2, 116). Latin was the official language of the army. Nevertheless, 'Latin was rarely obligatory' and 'many units functioned mainly in Greek', even if 'forms of bilingualism or a passive knowledge of Latin must have been widespread' with degrees of competence ranging from rudimentary knowledge to colloquial fluency as Adams (2004:617-618) concludes, refining the view that foreign recruits had to learn Latin as a second language. Papyri provide explicit evidence of the acquisition of Latin in the army by Greek-speaking soldiers, although 'the aim of such learning and instruction was not to enforce the use of Latin in all circumstances' (Adams 2004:618). A clear example of this is a glossary of military terminology preserved by a papyrus from the 3rd or 4th century, P.Strasb. inv. G 1173 (MP3 2134.61, LDAB 9218), having the Greek terms in the left column and the Latin equivalent transliterated into Greek script in the right column (11. 24-40) (cf. Dickey 2016:124-125; Kramer 2001:65-76, no. 6). Interestingly, besides words perfectly transliterated like $\kappa \alpha \sigma \tau \rho \alpha$ (1. 26, Lat. castra), $\mu \imath \lambda[\imath \tau 1] \alpha(1.25$, Lat. militia), $.1 \mu \pi \varepsilon \rho \alpha \tau \omega \rho$ (1. 29, Lat. imperator) and $\mu 1 \lambda ı \tau\rceil \varsigma$ (1. 26, Lat. milites), it presents

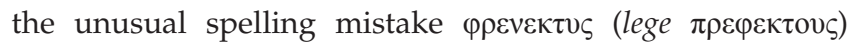

15.This has been demonstrated by Kramer 1983 and 2001 . For the medieval glossaries, see Goetz and Gundermann (1888), Goetz (1892) and Radiciotti (1998:49-118).

16.Compare Dickey (2015a:43-51; 2016:1, 144-148) for specimens. See also Scappaticcio (2015:472-477.)

17.For references to the papyri preserving these authors, see Sánchez-Ostiz (2013:145 with notes 7-11; cf. also Gaebel 1969-1970:287). $\kappa \alpha[\sigma \tau] \rho \omega \rho о \nu[\mu]$ (1. 31, Lat. praefectus castrorum), the erratic use of simple iota or the diphthong epsilon iota to represent Latin $i$

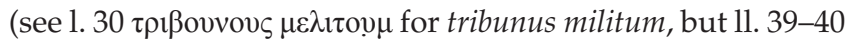

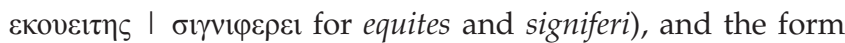
$\lambda \varepsilon \gamma 1 \omega v$ that does not reflect the transliteration of the nominative legio, but rather $\lambda \varepsilon \gamma 1 \omega$ v - a borrowing adapted to the Greek morphological system that has several attestations in papyri from the Roman Egypt.

Greek speakers could achieve either an active or a passive competence in Latin. If their profession required it, they could likely develop enough skills to write in decent Latin. However, the fact that there is only scanty evidence of composition exercises, seems to suggest that they were more interested in oral proficiency: the learning process was chiefly intended to read, to acquire or refine the pronunciation abilities, or even to speak without ever knowing the alphabet. ${ }^{18}$ A clue to this oral interest is represented by the high number of transliterated texts as well as by the presence of diacritics to assure correct pronunciation. The addition of learning aids, such as macrons, accents and diaereses, proves that Greek speakers could have difficulties with Latin quantities. Greeks distinguished long and short vowels with different letters ( $\eta$ and $\varepsilon, \omega$ and $o$ ). The fact that Latin had the same letters for different quantities, could appear confusing. Therefore, macrons were sometimes marked over long vowels, mostly long $e$ and $o$ : this indicates that the text was meant to be read aloud (cf. Cribiore 2007:61; Dickey 2015a:35, 46, 48; 2016:5; Scappaticcio 2015:13). Another potentially confusing aspect of Latin language could be the letter $h$, as it is demonstrated by a papyrus from the 5th or 6th century from Oxyrhynchus, P.Oxy. X 1315 descr. (MP3 3013, LDAB 4163) (cf. Dickey 2016:119; Kramer 2001:40-44, no. 2; Scappaticcio 2015:72). It is a learner's exercise providing the Latin alphabet in both capital and lower-case forms with the Greek equivalent on some of the Latin letters. In correspondence with the Latin $h$ the learners wrote $\eta$; thus making the mistake of equating a Latin consonant with a Greek vowel.

Among the Latin learning materials, the remainder of this article will focus on legal texts on papyrus to highlight the practical advantages of learning Latin in Roman Egypt.

\section{Legal materials on papyrus}

In the Roman Empire, all legal procedures were conducted in Latin, but this rule became flexible in those provinces, such as Egypt, where Greek remained the chief spoken language. ${ }^{19}$ Nevertheless, within the multilingual environment of Roman Egypt, Latin developed as a

18.According to Dickey (2016): ... a significant percentage of Latin learners did not learn the alphabet. Such learners must have been interested in oral proficiency rather than in the capacity to read or write, and it may well be that the majority of what they did is now lost to us because it was done orally and never written down. Some of these learners, however, have signaled their presence by producing transliterated Latin learning texts, with the Latin in Greek script. Such texts are more common than the ones with the Latin in Roman script until the third century ad but become fairly rare after that century. (p. 121; see pp. 121-127 for specimens of texts of this type)

19.Many legal texts, such as contracts, court proceedings and legislative acts, are preserved by Greek papyri dating back to the Roman and Byzantine time. See, for example, the contracts in P.Oxy. XXXVIII 2859 (AD 301), P.Mich. XIII 669 (VI cent. A.D.), and P.Ryl. 711 (VI cent. A.D.). In other cases, legal texts are written both in Latin and and P.Ryl. 711 (VI cent. A.D.). In other cases, legal texts are written both in Latin and
in Greek. See, for example, the 4th century fragments of judicial proceedings preserved by P.Ryl. IV 653, 654 and 702 (cf. Yiftach-Firanko 2009:541-550). 


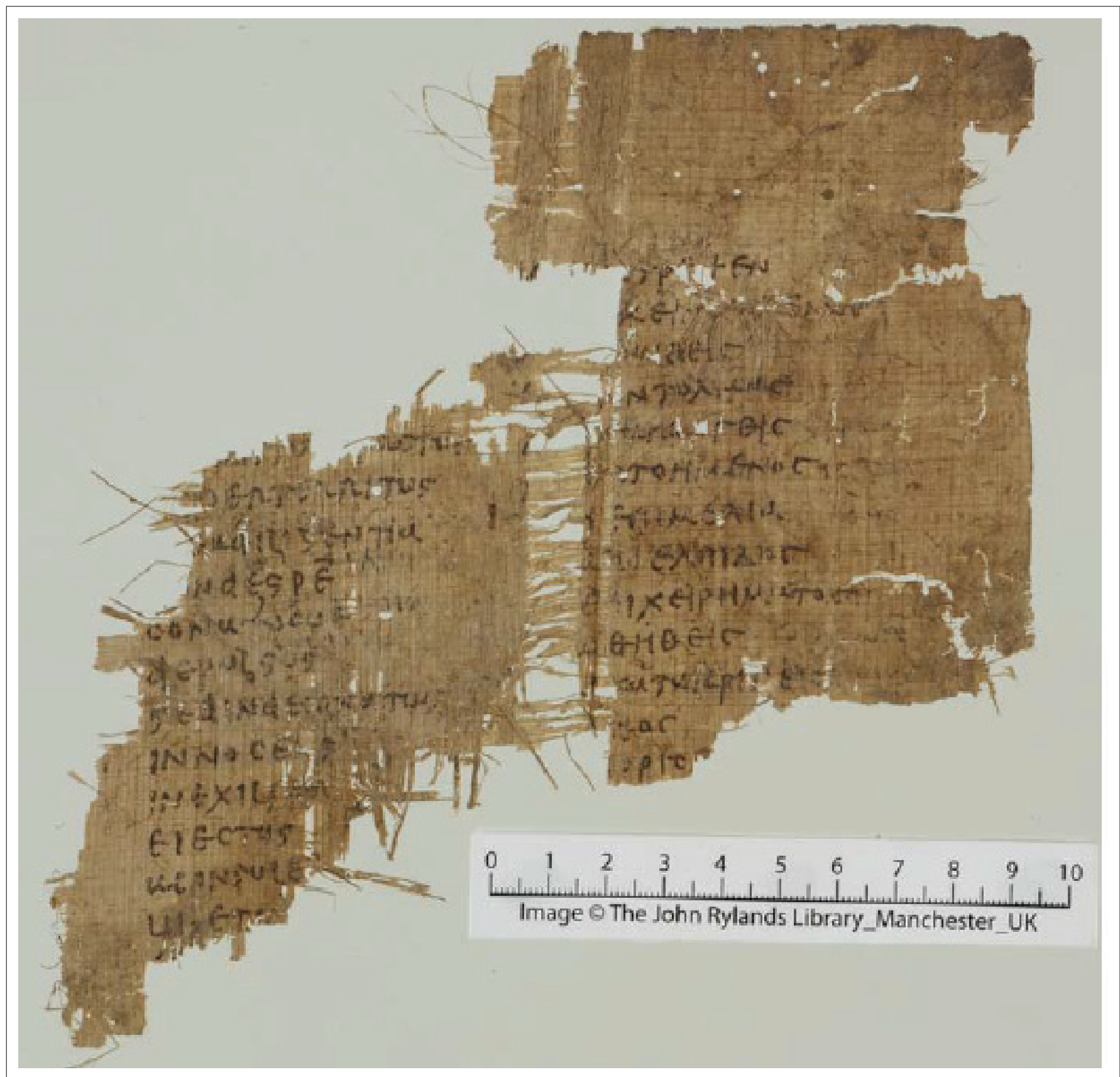

Source: The University of Manchester Library, n.d.(a), In Catilinam, viewed n.d., from: https://luna.manchester.ac.uk/luna/servlet/detail/ManchesterDev 93 3 55371 219698:InCatilinam? sort=reference_number $\% 2$ Cimage_sequence_number $\% 2$ Cimage_title $\% 2$ Cimage_number\&qvq=q:cicero; sort:reference_number $\% 2$ Cimage_sequence_number $\% 2$ Cimage_ title\%2Cimage_number; 1 : $:$ ManchesterDev $\sim 33^{\sim} 3 \&$ mi=3\&trs $=4$

Note: Part of a codex: Designed for a Greek-speaking reader with an imperfect knowledge of Latin.

FIGURE 1: Manchester, John Rylands University Library, P.Ryl. I 61 recto.

language of power and law. Especially from the 4th century on, some command of Latin became recommended to enter the legal profession, and students of law had to gain at least a smattering of Latin literacy. As Cribiore (2007) explains:

A cultural phenomenon which in late antiquity contributed to both the decline of Greek rhetoric and the advance of Latin in the eastern part of the empire was a change in the training of advocates. The literary advocate [...] started to lose ground before the technical advocate who learned Latin law. In past times, an advocate trained in Greek rhetoric relied on the knowledge of iurisconsulti in court, but from the fourth century on he had to master both fields. While the technique of argument he had learned was still useful, speeches became shorter, with less emphasis on style, and students increasingly felt it necessary to learn Roman law. (p. 57)

Then, as now, a person dealing with legal issues or undertaking a legal education gave particular attention to acquiring the technical vocabulary of the discipline. ${ }^{20}$ Therefore, special attention will be paid to texts on papyrus that might have served as a support to understand and

20.It is hard to reconstruct the Roman law curriculum in Egypt, as the only information on the topic comes from the school of Beirut, the most prominent law school in the East (cf. Schulz 1946:275-276; Gaebel 1969-1970:294; Cribiore 2007:57-58; East (cf. Schulz 1946:275-276; Gaebel 1969-1970:294; Cribiore 2007:57-58;
Internullo 2011-2012:31-32). Examples of law learning materials are some Internullo 2011-2012:31-32). Examples of law learning materials are some
colloquia preserved by the medieval manuscript tradition (see Dickey 2016:31-38) 
acquire legal technical terminology. Some passages of two Ciceronian papyri, P.Ryl. I 61 and III 477, are particularly significant in this regard. As already mentioned, Cicero was one of the privileged Latin writers in education and the most recent list of the Ciceronian papyri from Egypt, enumerates 10 records. $^{21}$ At least some of them were designed for Greek speakers imperfectly acquainted with Latin or were written by Greek scribes as their bilingual nature demonstrates as well as the influence of the Greek ductus on the Latin handwriting. ${ }^{22}$ Both P.Ryl. I 61 and III 477 are fragments of papyrus codices written in half-uncial script and date back to the 5th century. Therefore, they are concrete testimonies of the renewed interest in learning Latin from the 4 th century on.

P.Ryl. I 61 (MP3 2923, LDAB 554) preserves parts of In Catilinam 2.14-15. Its bilingual format and its paleographical indications suggest that this manuscript was intended to be used by a Greek speaker probably as a school text (see Figure 1). The same hand wrote both the Latin and the Greek, using a brown ink typical of the Byzantine period, and the shape of the Latin letters displays the interference of the Greek script. ${ }^{23}$ Also the marks of long quantities in 1.8 points to the use by a Greek speaker. The left column is occupied by the Latin words arranged in small groups or singly, whereas the parallel column offers a mechanical Greek translation verbum pro verbo: a means 'of simplifying the learning process' by providing a 'learning aid' (Gaebel 1969-1970:311). The papyrus has thus the form of a Greek wordlist to Cicero's text. $^{24}$ This structure is shared by three other papyri containing passages from the Catilinarians. ${ }^{25}$ Given the judicial nature of the Catilinarians, it is highly likely that Greeks, concerned with Roman law, such as law students, could have used these manuscripts to get acquainted with Latin legal discourse and vocabulary. The works of Cicero could thus have been useful to reach a better understanding of Roman law itself. The connection between these materials and the legal education system is also strengthened by several paleographical similarities between these didactic texts and the juridical codices produced in the pars Orientis of the Empire (cf. De Nonno 2009:249-278; Internullo 2011-2012:34; Radiciotti 2010:94). All these Ciceronian bilingual wordlists date back to the same timespan (late IV-V century). Thanks to the emperor, Theodosius II, in particular, who promoted the compilation 21.On the Ciceronian papyri, see Sanchez-Ostiz (2013:144-153, esp. p. 146 for the list).

22.Compare Sánchez-Ostiz (2013:148): 'graphemic interferences from one alphabet into the other were not infrequent among practised copyists whose mother tongue was not Latin'

23.For a paleographical analysis, see Internullo (2011-2012:81-83) with bibliography.

24.On the format of the wordlists, see Gaebel (1969-1970:284-285, 297-303), Sánchez-Ostiz (2013:147-148), Internullo (2011-2012:27, 34).

25.Compare P.Rainer. Cent. 163 (IV-V AD; MP3 2922, LDAB 554), PSI Congr. XXI 2 (V AD; MP3 2921.01, LDAB 556), P.Vindob. inv. L 127 (V AD; MP3 2923.1, LDAB 559). For a revised edition of the four papyri containing the Catilinarians, see Internullo (2011-2012:27-150). According to Maehler (1983:57-59), the last one and P.Ryl. 61 belong to the same codex, but Internullo (2011-2012:98-99) rejects this hypothesis.
BOX 1: The Latin and Greek texts according to the most recent edition of the papyrus.

\begin{tabular}{|c|c|c|}
\hline & $\begin{array}{l}\text { [conuerterit] } \\
\text { [non ille a me] } \\
\text { [spoliatus] } \\
\text { [armis audaciae] }\end{array}$ & 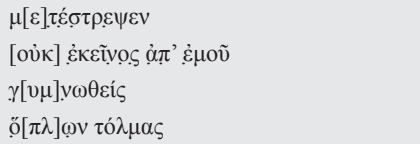 \\
\hline 5 & $\begin{array}{l}\text { [non] ọbṣtu[pe]f̣actus } \\
\text { [a]c̣ perterritus } \\
{[\mathrm{m}] \text { ẹa diligentia }} \\
{[\mathrm{n}] \text { on dē spē }} \\
\text { conațuque }\end{array}$ & 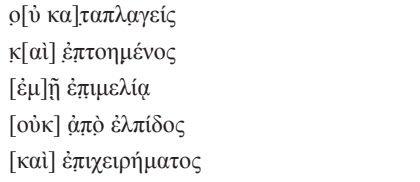 \\
\hline 10 & $\begin{array}{l}\text { depulsụs } \\
\text { sed indemnnatuṣ } \\
\text { innoceṇs } \\
\text { in exiliụm } \\
\text { eiectus }\end{array}$ & 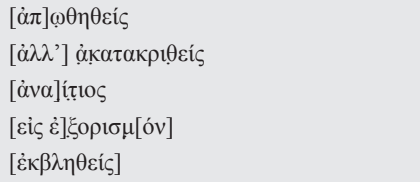 \\
\hline 15 & $\begin{array}{l}\text { a consulẹ } \\
\text { ui et } m[\text { inis] } \\
\text { ẹș }[\text { se dicetur] }\end{array}$ & 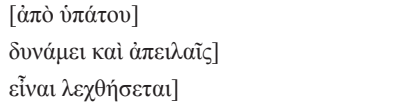 \\
\hline \multicolumn{3}{|c|}{ 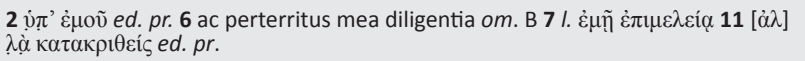 } \\
\hline \multicolumn{3}{|c|}{ 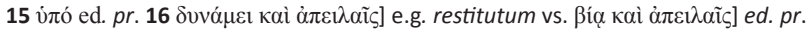 } \\
\hline \multicolumn{3}{|c|}{$\begin{array}{l}\text { [(scil. if Lucius Catiline) should turn (scil. to flight and exile), he will not be said to } \\
\text { have been stripped by me of the arms of his audacity, to have been astonished } \\
\text { and terrified by my diligence, to have been frustrated of his hope and his } \\
\text { enterprise, but, uncondemned and innocent, to have been driven into exile by } \\
\text { the consul by means of threats and violence.] [author's translation] }\end{array}$} \\
\hline
\end{tabular}

of the law code known as Codex Theodosianus, it corresponds to the period during which the study of Latin in the eastern provinces contributed to 'a Greek Roman Empire', according to the definition given by Millar $(2006: 91-93) .^{26}$

To illustrate the format and the arrangement of the text, 11 . 1-17 of the manuscript are given in Box $1 .^{27}$ The Latin and Greek texts are supplied according to the most recent edition of the papyrus (Hunt 1911:193-194; Internullo 20112012:79-94).

The other Ciceronian papyrus, P.Ryl. III 477 (MP3 2919, LDAB 558), ${ }^{28}$ is a bifolium preserving part of the sections 35-37 and 44-46 of the Divinatio in Q. Caecilium, and represents one of the most significant papyrological contributions to the text of the speeches In Verrem. ${ }^{29}$ It is not a wordlist such as in the previous case, but a standard text with diacritical marks, occasional punctuation and many marginalia in Latin and Greek. The hands of five different scribes can be identified. The scribes or annotators squeezed a considerable bulk of material in the margins. Most of the Greek annotations consist of adaptations or translations of the Latin text, but what makes this papyrus remarkably noteworthy is a Greek scholium about the Roman juridical

26.Compare Internullo (2011-2012:35) with bibliography.

27.The papyrus is housed at The John Rylands University Library of Manchester (reference number: Greek P 61). The digital image of the papyrus, here reproduced as Figure 1, is freely accessible at the link: https://luna.manchester.ac.uk/luna/ servlet/detail/ManchesterDev 93 3 55371 219698?qvq=q\%3AGreek $\% 20 \mathrm{P} \%$ $2061 \& \mathrm{mi}=1 \&$ trs $=4$.

28.Ed. pr. Roberts 1938:72-77. The text has also been published by Cavenaile (1958:75-78) as CPL 23.

29.The other Egyptian papyri, containing fragments of the Verrines, are P.land. V 90r (I AD; MP3 2920, LDAB 561), P.Oxy. VIII 1097 + X 1251 (V AD; MP3 2918, LDAB 557) and PSI I 20 (V-VI AD; MP3 2919.1, LDAB 560). 


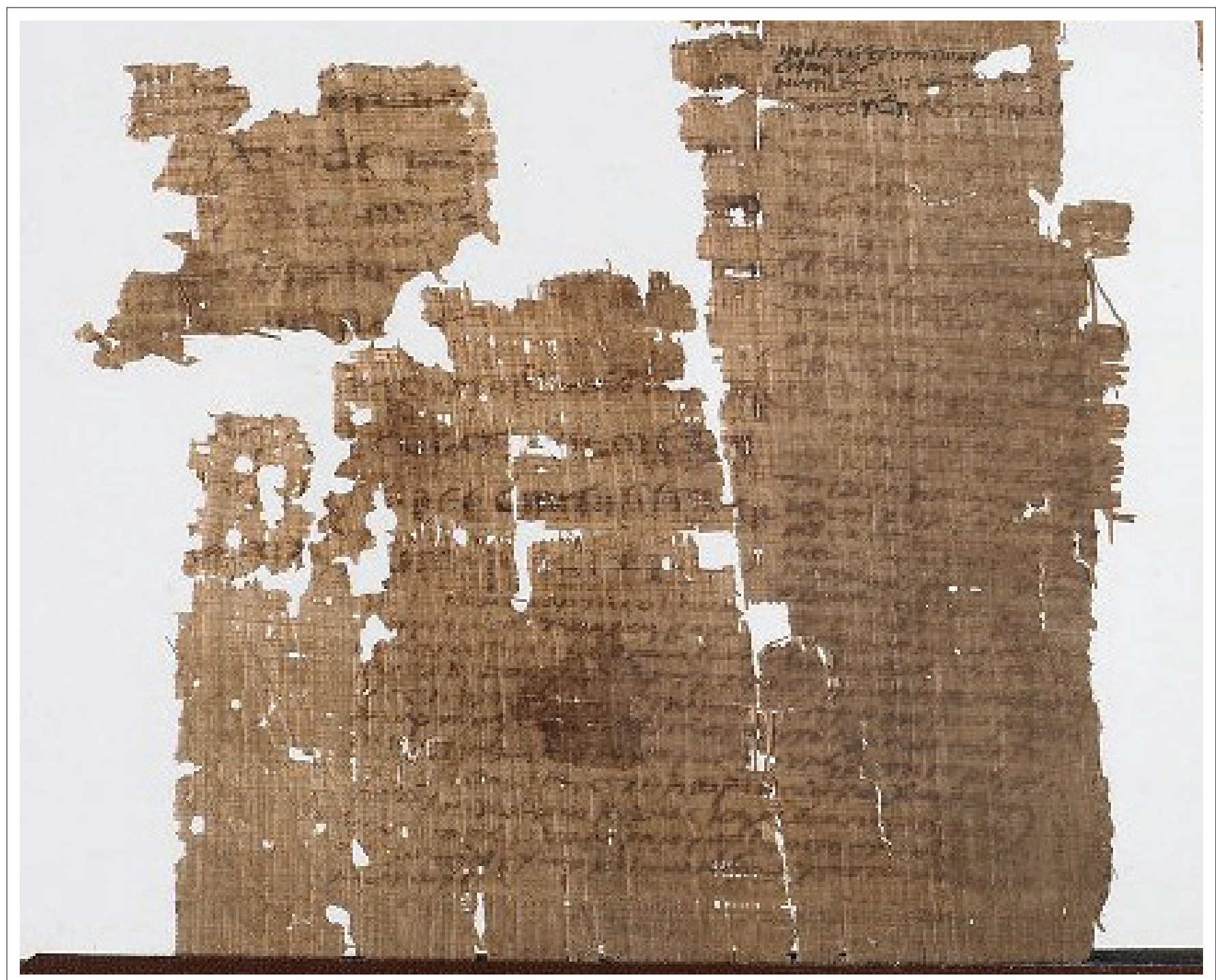

Source: The University of Manchester Library, n.d.(b), Divinatio in Q. Caecilium, viewed n.d., from: https://luna.manchester.ac.uk/luna/servlet/detail/ManchesterDev 93 3 37322 100512:Divina tio-in-Q--Caecilium?sort=reference_number $\% 2$ Cimage_sequence_number $\% 2$ Cimage_title $\% 2$ Cimage_number\&qvq=q:cicero; sort:reference_number $\% 2$ Cimage_sequence_number $\% 2$ Cimage_ title\%2Cimage_number;lc:ManchesterDev 93 3\&mi=1\&trs=4

Note: This bifolium contains parts of sections of the Divinatio. The text is written in a consistent and regular half-uncial. The text is heavily annotated, the bulk of notes and glosses being written in a small, slightly sloping Greek hand. There are possibly five different scribes.

FIGURE 2: Manchester, John Rylands University Library, P.Ryl. III 477, Fol. I recto (detail).

term indicium, appearing in section 34, line 5 of the Ciceronian text (si tibi indicium postulas dari quod tecum una fecerit, concedo, si id lege permittitur, 'if you demand to be allowed to give information regarding the crimes which [scil. Verres] has committed together with you, I have no objection, if it is allowed by the law'). This note (c), following two brief notes in Latin (a, b), stands out among surviving marginal annotations on papyrus for its content and unparalleled length (see McNamee 2007:80-81). The scholium occupies a considerable portion of the outer edge of Fol. 1 recto (see Figure 2$)^{30}$ and sneaks into the bottom margin. It comments upon the meaning of this legal term by providing

30.The papyrus is housed at The John Rylands University Library of Manchester (reference number: Greek P 477). The digital image of the whole papyrus, from which the detail, here reproduced as Figure 2 , has been taken, is freely accessible at the link: https://luna.manchester.ac.uk/luna/servlet/detail/ManchesterDev 93 3 37322 https://luna.manchester.ac.uk/luna/servlet/detail/ManchesterDev 93 3 37322 100512 ? qvq $=q \% 3$ Acicero $\% 3$ Bsort $\% 3$ Areference number $\% 2$ Cimage_sequence
number $\% 2$ Cmetadata schema\& $\&$ mi $=22 \&$ trs $=44$. Note the mistake in the collection: number $\% 2 \mathrm{Cmetadata} s \mathrm{schema} \& \mathrm{mi}=22 \& \mathrm{tr}=44$. Note the mistake in the collection:
the fragments of the papyrus are misplaced under the glasses preserving them, the fragments of the papyrus are misplaced und
and Fol. I recto at this link is indicated as verso. unprecedented details. After starting with an explanation of the rules related to the status of informers, it goes on paraphrasing and expanding Cicero's contents (Box 2).

Like in the previous case, the nature of this manuscript, and in particular, the length and the content of this annotation suggest that the papyrus was intended for a native Greek speaker interested in legal issues. It is possible that its owner used this copy of heavily annotated Ciceronian text as a support to the comprehension of Roman law and the acquisition of its technical terminology. To quote McNamee's words (2007):

This may be mere coincidence, but in view of the importance of fifth-century legal scriptoria in the development of large-format books with heavy annotation, it is tempting to speculate that the owner of this Cicero had a professional interest, not just a literary one, in the legal ramifications of this part of the speech. (p. 81; see Internullo 2011-2012:34, n. 31) 
BOX 2: Paraphrasing and expanding Cicero's contents

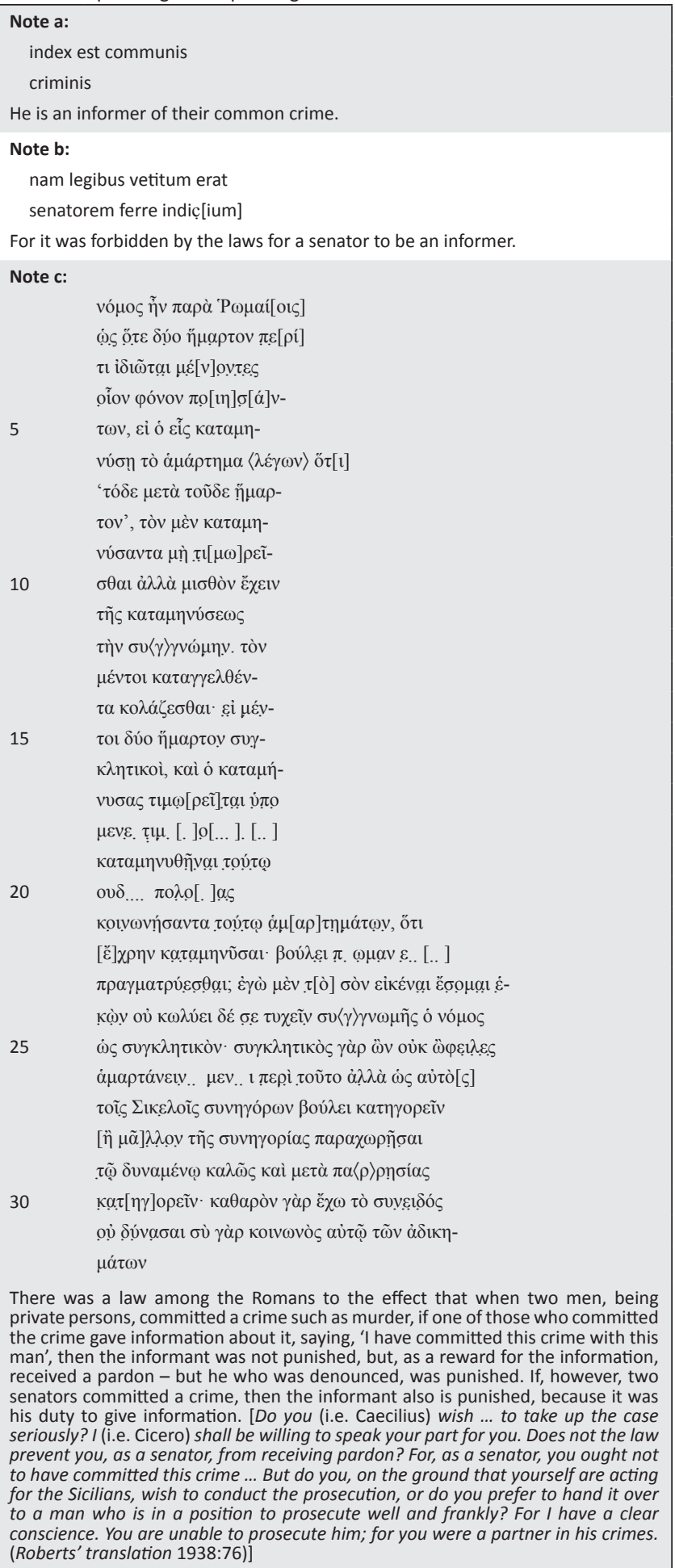

\section{Conclusion}

\section{Latin and Law between past and present}

Latin learning materials on papyrus, designed for Greek speakers concerned with Roman law, allow us to draw parallels between ancient and present teaching of Latin in the context of legal studies. As is widely recognised, Latin played a pivotal role in the history of the development of law in past centuries, and it gained the status of common legal language applied across the boundaries of local law and different legal cultures. The impact of Latin law on the modern legal systems has been significant in several countries, not only in Europe. Although its use is less prevalent than in the past, Latin still retains a high status in legal writing and terminology, thanks to the occurrence of Latin juridical terms, abbreviations and phrases. This is also the case in South Africa today. Modern South African law is based on Roman-Dutch law - the legal system produced by the synthesis of Dutch law developed from Germanic customary law and Roman law (Du Toit 2014:278-281). As a concrete proof of this, modern law reports demonstrate how and to what extent Roman legal sources and principles can still be applied in South African court cases (Strynex 1993:395-407; Zietsman 2000:75-87). Therefore, some knowledge of Latin is advisable in view of a better understanding of Roman law (cf. Zimmerman 1986:605), even if teaching Latin to students of law within a decolonised university curriculum is currently a matter of debate. ${ }^{31}$

The 'formative' value of Latin and the intellectual, linguistic and cultural benefits of its teaching to law students in South Africa have been stressed in recent years by Dircksen (2010:117-128). Dircksen (2010):

\footnotetext{
... reviews both the traditional arguments in favour of the retention of Latin as a compulsory university course for law students in South Africa and the reasons for its abolishment in 1996 [concluding] 'A proper understanding of Latin legal maxims, correct pronunciation of Latin words and the practical and functional use of a Latin dictionary will add to the subject's practical usefulness. If classicists adapt their methods according to these 'new' outcomes, Latin, which used to be labelled the 'obstacle' in the path of future legal practitioners, will smooth the way for them and in the long run improve the quality and standing of legal practice in South Africa in general.' (p. 117)
}

Some law students undertake Latin studies for one academic year without having any previous knowledge of it. The first year Latin courses are mostly focused on the acquisition of the basics of grammar, but they can also include lessons illustrating relevant aspects of Roman culture, religion and society, especially when helpful to understand the historical background and development of Roman law. Some beginner's textbooks are specifically devoted to approach legal Latin (cf. e.g. Emanuel 1998; Hilton Jackson 1915'; Sodhi \& Vasan 1980; Versteeg 1990). Volumes on the topic published in South Africa, hence destined also to South African law students and lawyers, are the Glossarium of Latin words and phrases by Rood (2003) and the basic course authored by Scholtemeijer and Hasse $\left(1989^{1}\right)$, which is available also in Afrikaans under the title Regslatyn - 'n kernkursus. Selected extracts from Gaius' Institutiones, an introductory textbook of legal institutions designed for ancient law students and written approximately AD 160, serve as target text, because it 'provides an adequate basis for reading other legal works' (p. IX). Easy passages from Iustinian's Institutiones, one of the units of the Corpus Iuris Civilis, which has Gaius's work as main source text, can also be used as didactic material. Furthermore, students are supplied with lists of legal Latin maxims, which they will come across in their careers as 31.On the topic, see the article by A. Geduld (2019) in this same volume. 
lawyers. A direct approach between South African first year law students and Latin texts is thus limited to Gaius, Iustinian and Latin maxims, which provide the only occasion to learn terminology in context. Classical Latin authors receive more attention only if law students carry on with the study of Latin in the second or even third year. In such a case, they can read some of Cicero's orations exactly as their ancient colleagues used to do, according to the evidence of the papyri.

The comparison between ancient and modern Latin learning materials in the training of law students enables us to outline the following similarities between past and present:

- Latin was and is learned with the practical aim of using it in the legal profession;

- ancient and modern learning materials make use of macrons and accents to indicate correct pronunciation of Latin words;

- the acquisition of the technical vocabulary of the discipline was and still is considered of primary importance and both ancient and modern learning materials can include the explanation of the relevant Roman legal terminology;

- thestudy of Latin canstill contribute to abetter understanding of the meaning of legal concepts: many concepts in modern law as well as in Roman law have Latin names or names derived from Latin, and many commonly used legal principles are expressed in form of Latin sententiae.

These similarities emphasise the importance of reviving the voice of the past through the study of its direct sources as well as the influence that this voice continues to have on the modern world.

\section{Acknowledgements}

I would like to express my special thanks of gratitude to Dr Johan Steenkamp for his constructive criticism, motivation and friendly advice during the writing of this article. I would also like to extend my gratitude to Prof. Marianne Dircksen and Prof. Christoff Zietsman for providing me with suggestions and materials on the topic of legal Latin in South Africa.

\section{Competing interests}

I declare that I have no financial or personal relationships which may have inappropriately influenced me in writing this article.

\section{Author's contributions}

I declare that I am the sole author of this research article.

\section{Ethical consideration}

I confirm that ethical clearance was not needed or required for the study.

\section{Funding information}

This research received no specific grant from any funding agency in the public, commercial, or not-for-profit sectors.

\section{Data availability statement}

Data sharing is not applicable to this article as no new data were created or analysed in this study.

\section{Disclaimer}

The views and opinions expressed in this article are those of the authors and do not necessarily reflect the official policy or position of any affiliated agency of the authors.

\section{References}

Adams, J.N., 2004, Bilingualism and the Latin Language, Cambridge University Press, Cambridge.

Brashear, W., 1981, 'A Greek-Latin Vocabulary', in R.S. Bagnall, G.M. Browne, A.E. Hanson \& L. Koenen (eds.), Proceedings of the XVI International Congress of Papyrology, pp. 31-41, Scholars Press, Chicago, IL.

Cavenaile, R., 1958, Corpus Papyrorum Latinarum, Harrassowitz, Wiesbaden.

Cribiore, R., 1996, Writing, teachers and students in Graeco-Roman Egypt, Scholars Press, Atlanta, GA.

Cribiore, R., 1997, 'Literary School Exercises', Zeitschrift für Papyrologie und Epigraphik (ZPE) 116, 53-60.

Cribiore, R., 2007, 'Higher education in Early Byzantine Egypt: Rhetoric, Latin, and the Law', in R.S. Bagnall (ed.), Egypt in the Byzantine World, 300-700, pp. 47-66, Cambridge University Press, Cambridge.

Cribiore, R., 2009. 'Education in the Papyri', in R.S. Bagnall (ed.), The Oxford Handbook of Papyrology, pp. 320-337, Oxford University Press, Oxford.

De Nonno, M., 2009, 'Ars Prisciani Caesariensis: Problemi di tipologia e composizione', in M. Baratin, B. Colombat \& L. Holtz (eds.), Priscien. Transmission et refondation de la grammaire de l'antiquite aux modernes (état de recherches à suite du colloque international de Lyon, 10-10 octobre 2006), Studia Aristarum 21 , pp. 249-278, Brepols, Turnhout.

Dickey, E., 2015a, 'Teaching Latin to Greek Speakers in Antiquity', in J.E.P. Archibald, W. Brockliss, \& J. Gnoza (eds.), Learning Latin and Greek from Antiquity to Present, pp. 30-51, Cambridge University Press, Cambridge.

Dickey, E., 2015b, 'Columnar translation: An ancient interpretive tool that the Romans gave the Greeks', CQ 65, 807-821. https://doi.org/10.1017/S00098388 15000087

Dickey, E., 2016, Learning Latin the Ancient Way. Latin Textbooks from the Ancient World, Cambridge University Press, Cambridge.

Dircksen, M. 2010, 'Latyn en die opleiding van regstudente in Suid-Afrika: 'n Nuwe relevansie', De jure 43(1), 117-128.

Du Toit, F., 2014, 'Roman-Dutch Law in Modern South African Succession Law', Ars Aequi April 2014, 278-285.

Emanuel, S.L., 1998, Latin for lawyers: The language of the law, Emanuel Publisher Corporation, New York.

Evans, T.V., 2012, 'Latin in Egypt', in C. Riggs (ed.), The Oxford Handbook of Roman Egypt, pp. 516-525, Oxford University Press, Oxford.

Fournet, J.L., 2009, 'The Multilingual Environment of Late Antique Egypt: Greek, Latin, Coptic, and Persian Documentation', in R.S. Bagnall (ed.), The Oxford Handbook of Papyrology, pp. 418-451, Oxford University Press, Oxford.

Gaebel, R. E., 1969-1970, 'The Greek Word-Lists to Vergil and Cicero', BRL 52, 284-325. https://doi.org/10.7227/BJRL.52.2.4

Geduld, A.J.N., 2019, 'Teaching Latin to law students in the midst of the decolonisation of the university curriculum', In die Skriflig 53(2), [not published yet]

Goetz, G., 1892, Hermeneumata Pseudodositheana (CGL III), Teubner, Lipsiae.

Goetz, G. \& Gundermann, G., 1888, Glossae Latinograecae et Graecolatinae (CGL II), Teubner, Lipsiae.

Hilton Jackson, E., $1915^{1}$ (rep. 2014), Latin for Lawyers. Containing: I: A Course in Latin, with Legal Maxims \& Phrases as a Basis of Instruction II. A Collection of Over 1000 Latin Maxims, Sweet \& Maxwell, London.

Hunt, A.S., 1911, Catalogue of the Greek Papyri in the John Rylands Library, Manchester, vol. I: Literary Texts (nos. 1-61), Manchester University Press, Manchester.

Internullo, D., 2011-2012, 'Cicerone latinogreco. Corpus dei papiri bilingui delle Catilinarie di Cicerone', Papyrologica Lupiensia 20-21, 25-152.

Kramer, J., 1983, Glossaria bilinguia in papyris et membranis reperta, Habelt, Bonn.

Kramer, J., 2001, Glossaria bilinguia altera, Saur, München.

Maehler, H., 1983, 'Bemerkungen zu dem neuen Cicero-Fragment in Wien', Zeitschrift für Papyrologie und Epigraphik (ZPE) 52, 57-59.

McNamee, K., 2007, Annotations in Greek and Latin Texts from Egypt, American Society of Papyrologists, New Haven, CT.

Millar, F., 2006, A Greek Roman Empire: Power and belief under Theodosius (408-450), University of California Press, Berkeley, CA. 
Mertens-Pack 3 (MP3), n.d., Mertens-Pack 3 online database, Liège, Belgium, viewed 28 March 2019, from http://cipl93.philo.ulg.ac.be/Cedopal/MP3/dbsearch.aspx

Oates, J.F. \& Willis, W.H., 2011, 'Checklist of Greek, Latin, Demotic and Coptic Papyri, Ostraca and Tablets', viewed 10 May 2019, from https://library.duke.edu/ rubenstein/scriptorium/papyrus/texts/clist.html

Radiciotti, P., 1998, 'Manoscritti digrafici grecolatini e latinogreci nell'alto medioevo', Römische historische Mitteilungen 40, 49-118.

Radiciotti, P., 2010, 'Virgilio: le fonti di interesse papirologico esaminate da un paleografo', Scripta 3, 89-96.

Roberts, C.H., 1938, Catalogue of the Greek Papyri in the John Rylands Library, Manchester, vol. III: Theological and Literary Texts (nos. 457-551), Manchester University Press, Manchester.

Rochette, B., 1996a, 'Sur le bilinguisme dans l'Égypte gréco-romaine', CE 71, 153-168. https://doi.org/10.1484/J.CDE.2.309013

Rochette, B., 1996b, 'Papyrologica bilinguia Graeco-latina', Aegyptus 76, 57-79.

Rochette, B., 1997, Le latin dans le monde grec: Recherches sur la diffusion de la langue et des lettres latines dans les provinces hellénophones de l'empire romain, Latomus, Brussels.

Rochette, B., 2010, 'Greek and Latin Bilingualism', in E.J. Bakker (ed.) A Companion to the Ancient Greek Language, pp. 281-293, Wiley Blackwell, Malden, MA.

Rood, T.B., 2003, Glossarium: A compilation of Latin words and phrases generally used in Law with English Translations, Proctrust Publications, Bryanston.

Sánchez-Ostiz, Á., 2013, 'Cicero Graecus: Notes on Ciceronian Papyri from Egypt', Zeitschrift für Papyrologie und Epigraphik (ZPE) 187, 144-153.

Scappaticcio, M.C., 2015, Artes Grammaticae in frammenti. I testi grammaticali latin e bilingui greco-latini su papiro, Edizione commentate, De Gruyter, Berlin.
Scholtemeijer, J. \& Hasse, P., 1989 ${ }^{1}$, Legal Latin: A basic course, J.L. van Schaik Academic, Pretoria.

Schulz, R.W., 1974, History of Roman Legal Science, Oxford University Press, Oxford.

Sodhi, D. \& Vasan, R.S., 1980, Latin Words \& Phrases for Lawyers, Law and Business Publications, New York.

Strynex, M., 1993, Commercial Law Reports 1993 - Judgments of the Courts of South Africa, The Law Publisher CC, Durban.

The University of Manchester Library, n.d.(a), In Catilinam, viewed n.d., from https:// luna.manchester.ac.uk/luna/servlet/detail/ManchesterDev 93 3 55371 219698: In-Catilinam?sort=reference number\%2Cimage sequence number $\% 2$ Cimage In-Catilinam?sort=reference_number $\% 2$ Cimage_sequence_number $\% 2$ Cimage
title $\% 2$ Cimage_number\&qvq=q:cicero; sort:reference_number $\% 2$ Cimage title $\% 2$ Cimage_number\&qvq=q:cicero; sort:reference_number $\% 2$ Cimage
sequence number $\% 2$ Cimage title $\% 2$ Cimage_number;lc:ManchesterDev $93 \sim 38$ sequence_num
$\mathrm{mi}=3 \& \operatorname{trs}=4$

The University of Manchester Library, n.d.(b), Divinatio in Q. Caecilium, viewed n.d., from: https://luna.manchester.ac.uk/luna/servlet/detail/ManchesterDev 93 $3^{\sim}$ from: https://luna.manchester.ac.uk/luna/servlet/detail/ManchesterDev 93 3 $37322 \sim 100512$ :Divinatio-in-Q--Caecilium?sort=reference_number\%2Cimage
sequence number $\% 2$ Cimage title $\% 2$ Cimage number\&qvq=q:cicero;sort:refere sequence_number $\% 2$ Cimage_title $\% 2$ Cimage_number\&qvq $=q$ :cicero;sort:refere
nce number $\% 2$ Cimage sequence_number $\% 2$ Cimage_title $\% 2$ Cimage_number; nce_number\%2Cimage_sequence_n
c:ManchesterDev $\sim 23 \sim 3 \& \mathrm{mi}=1 \&$ trs $=4$

Trismegistos (LDAB), n.d., Leuven Database of Ancient Books, Leuven, Belgium, viewed 07 April 2019, from https://www.trismegistos.org/ldab/

Versteeg, R., 1990, Essential Latin for Lawyers, Carolina Academic Press, Durham.

Yiftach-Firanko, U., 2009, Law in Graeco-Roman Egypt: Hellenization, Fusion, Romanization in R.S. Bagnall (ed.), The Oxford Handbook of Papyrology, pp. 541-560, Oxford University Press, Oxford.

Zietsman, C., 2000, 'Vicious dogs: A case study from 2000 BC to 2000 AD', Akroterion 45, 75-87. https://doi.org/10.7445/45-0-165

Zimmerman, R., 1986, 'Latin for Lawyers', De rebus 228, 605-606. 